\title{
Erratum to: Corporate Socially Responsible Initiatives and Their Effects on Consumption of Green Products
}

\author{
Simona Romani · Silvia Grappi · Richard P. Bagozzi
}

Published online: 14 January 2015

(C) Springer Science+Business Media Dordrecht 2015

\section{Erratum to: J Bus Ethics}

DOI 10.1007/s10551-014-2485-0

The authors of the above-mentioned article would like to add the following paragraph:

The online version of the original article can be found under doi:10.1007/s10551-014-2485-0.

S. Romani

LUISS, Viale Romania, 32, 00197 Rome, Italy

e-mail: sromani@luiss.it

S. Grappi $(\bowtie)$

University of Modena and Reggio Emilia, Viale Berengario 51,

41100 Modena, Italy

e-mail: silvia.grappi@unimore.it

R. P. Bagozzi

Stephen M. Ross School of Business, The University of

Michigan, 701 Tappan Street, Ann Arbor, MI, USA

e-mail: bagozzi@umich.edu

Acknowledgments The authors would like to thank Unicoop Firenze for the precious assistance during the research process. 